\title{
Economic Assessment of the Productive Parameters in Meat Sheep Production Using Discrete Event and Agent-Based Simulation
}

Thayla Sara Soares Stivari Reijers, Gustavo Lineu Sartorello, Oscar Alejandro Ojeda-Rojas

School of Veterinary Medicine and Animal Science, University of Sao Paulo, Brazil

Camila Raineri

Federal University of Uberlândia, Brazil

Marcos Nogueira, Rodolfo Silva, Thiago Barros Brito

Polytechnic School, University of Sao Paulo, Brazil

Alda Lúcia Gomes Monteiro

Federal University of Parana, Brazil

Augusto Hauber Gameiro (Corresponding author)

School of Veterinary Medicine and Animal Science, University of Sao Paulo, Brazil

Received: June 10, 2019 Accepted: July 9, $2019 \quad$ Published: July 21, 2019

doi:10.5296/jas.v7i3.14904 URL: https://doi.org/10.5296/jas.v7i3.14904

\begin{abstract}
A hybrid stochastic model was developed including discrete events and agent-based simulations in order to identify the productive parameters and management criteria that most affect meat sheep production. A sheep herd on a pasture termination system, without weaning and with natural mating, was outlined. In order to devise this herd, a pre-existing database from between 1999 and 2013 was used. This conceptual model included the flushing, mating, gestation, lactation, termination and maintenance phases. Health, feeding and management criteria were also considered and recommended. Simulation scenarios were built which were later evaluated by regression analysis. The net operational margin was between $\mathrm{R} \$ 11741.80$ and $\mathrm{R} \$ 21389.80$, and an average of $\mathrm{R} \$ 14412.14 \pm \mathrm{R} \$ 3873.02$ for different scenarios. Food costs had the greatest impact $(25.4 \%)$ in relation to operating costs, while health costs were the lowest $(1.3 \%)$. The abortion rate showed a higher linear response in contrast to the birth rate and the net operating margin, upon analysing ewe productivity parameters. However, neonatal mortality showed the greatest impact on net profit and on general lamb mortality. Carrying out economic analyses within the livestock sector can make a difference
\end{abstract}


within such a competitive market, where prices are not controlled, only costs. The use of discrete event and agent-based simulation methodologies allowed for the assessment of different approaches to sheep production. The present study demonstrated the tool's potential within the scope of meat sheep production, but this model can act as a guideline for other animal production systems.

Keywords: computer simulation, hybrid model, operational research, production costs, profitability, stochastic

\section{Introduction}

Enterprise size and complexity growth meant that the managerial decision-making process, once conducted by intuition and previous experiences, is now guided by more elaborate problem solution analyses. These analyses can be performed by Operational Research (OR), whose main objective is the development of suitable, rational decision-making models (Machline et al., 1975). One of the most developed OR techniques is simulation. Simulation is a flexible, powerful and intuitive tool in situations when one has to work with numerous constraints that cannot be dealt with by classical methods (Hillier \& Lieberman, 2006).

In animal production, however, research lines including agent-based simulation (ABS) and/or discrete event simulation (DES) application are still limited. Several methods are available to calculate production costs, which is a key indicator for the feasibility analysis of a project. Nevertheless, the use of these methods in agricultural production still involves several technic and scientific issues. The challenge is allowing the projection of the activity in the productive horizon to be as real and dynamic as possible. The use of simulation models, which add probability to animal production, can be a technical alternative, as well as allow for the evaluation of the effects of research results and the identification of constraints that may encourage the development of future research.

Meat sheep production is considered a developing sector in Brazil. The national herd has increased by $13 \%$, as compared to $9 \%$ growth of the cattle herd, between 2007 and 2016 (FAO, 2017). Nevertheless, this activity lacks well-defined technological standards, which raises questions as to which management system should be adopted and leads to existing production bottlenecks. The analysis of the economic impact of animal performance within different scenarios for specific productive periods can help to understand their performance within each productive phase of meat sheep production.

This study aimed to generate a tool to exploit the potential of both discrete event and agent-based simulation methodologies, offering technicians and scientists a new method for useful analysis. The present study exploited its applicability in the analysis and identification of the productive parameters that most impact meat sheep production, as well as in the identification of specific feasibility and economic issues that affect the activity within the production cycle.

\section{Material and Methods}

The "Ethic Committee on the Use of Animals" certified that this research was in accordance with the ethical principles for animal research adopted by the institution. The process 
protocol number was 3027/2013, and it was approved in the meeting held on 26 June, 2013.

According to Harrell \& Bateman (2002), simulation is the process of the experimentation of a real system on a simplified model, which has widespread methodologies. The main sources for this topic are texts by Banks \& Carson (1984), Law \& Kelton (1991) and Pegden et al. (1995), which were compiled by De Freitas Filho (2008) in Brazil, and were used as methodological principles in the present study. Conforming to Montevechi et al. (2010), every simulation study has three major steps: design, implementation and analysis.

\section{Step design}

It includes project planning. We used data obtained from historical records of herd management and sheep herd research carried out by Laboratory of Production and Research of Sheep and Goats of Federal University of Parana (LAPOC/UFPR) between 1999 and 2013, as well as from the cost and profitability analysis sheets developed by Stivari (2012). By 2013, the LAPOC/UFPR herd was mostly made up of Suffolk and Suffolk crossbreds x mixed breeds; however, Santa Inês, White Dorper and crossbred specimens of these breeds were also included. Due to the significant performance differences between the Santa Inês and White Dorper breeds and their crosses, as compared to Suffolk, and also due to the greater availability of information on Suffolk and crossbred animals, only information on Suffolk and crossbred animals was used, so that there was no need to consider genetic merit at this stage of research.

The data were compiled by year and by activity, totaling a database with approximately 140 thousand items of information. Based on this information, descriptive statistical analyses to identify interactions and/or incongruities, and statistical distributions and frequencies, were performed with Minitab® (version 16.1), Input Anlyser ${ }^{\circledR}$ (version 14.7) and, Excel® (version 2013). $\mathrm{P}$ value was calculated for the adherence of the distributions according to the chi-square test at 0.05 of significance (further details of the analyses can be found in (Reijers, 2016).

The software chosen for the development of the model was AnyLogic ${ }^{\circ}$, University, 7.1.2 (XJ Technologies).

According to studies by Barros (2008), Barros et al., (2009a), Barros et al., (2009b), Stivari, (2012), Kowalski et al., (2013) and Stivari et al., (2013), of all the systems already used in the LAPOC/UFPR, which adopts lamb termination without weaning on pasture produced the best economic results. This system was used in this research.

Conceptual modelling - at the design stage - involves outlining the system by defining the components and describing the variables and logical interactions that account for the system (De Freitas Filho, 2008). Four experts in the area, using the face-to-face technique, as suggested by Sargent (2010), validated the conceptual model of this study. 


\section{Macrothink}

Journal of Agricultural Studies

ISSN 2166-0379

2019, Vol. 7, No. 3

A conceptual model flowchart is shown in Figure 1. The blocks were grouped into five main stages: flushing, mating season, gestation, lactation and termination.

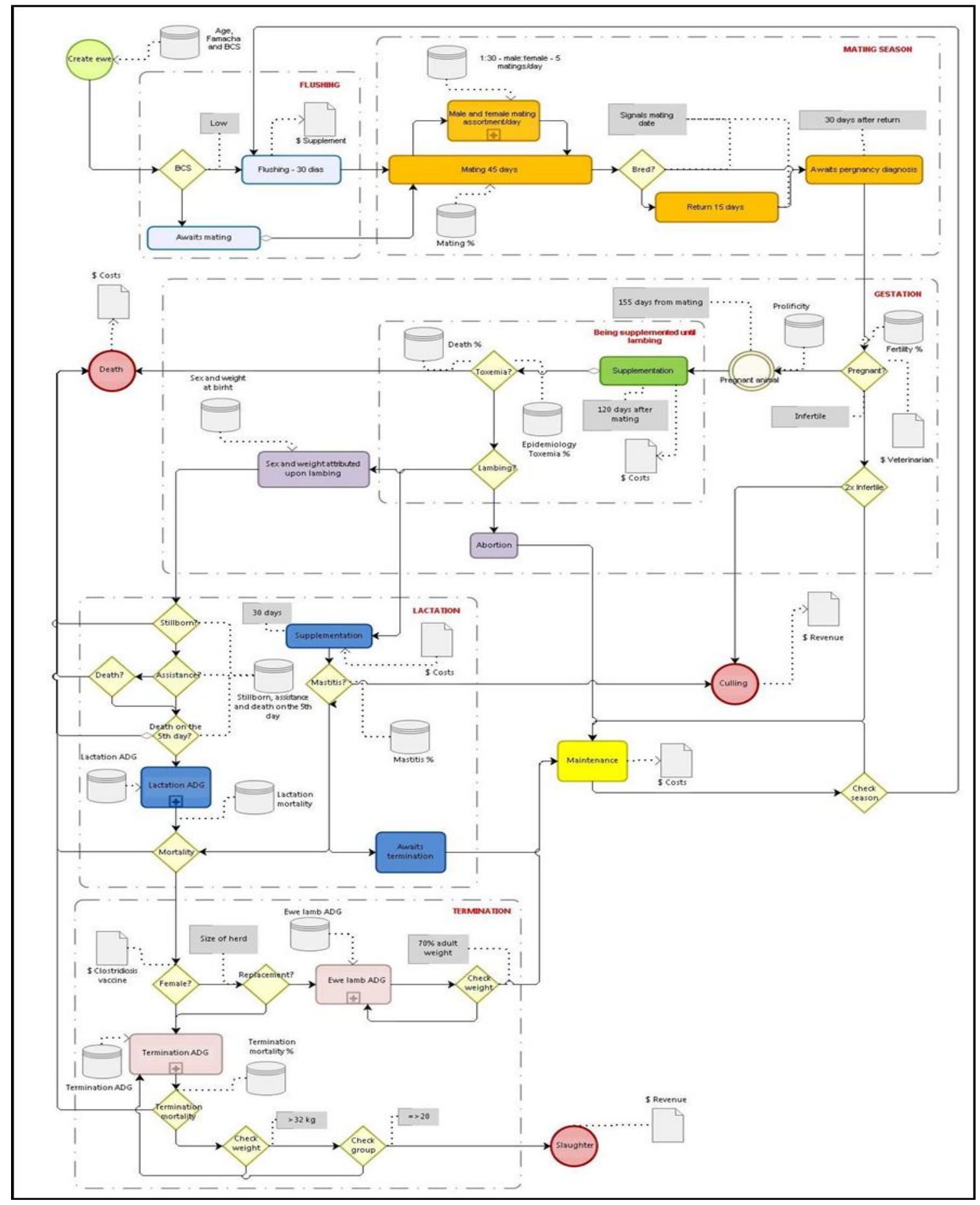

Figure 1. Conceptual model of a hybrid production system through the use of agent-based and discrete-event simulation methodologies

Continuous horizontal lines correspond to affirmative actions; continuous vertical lines correspond to negative actions; rectangles correspond to processes; diamonds correspond to decision-making; cylinders correspond to inputs; and paper sheet-shaped elements correspond to outputs. BCS: Body Condition Score 
Ewes and rams were considered model agents. Fully developed ewes were given individual attributes with respect to age, body condition score (BCS), Famacha score - based on an anaemia indicator by Van Wyk \& Bath (2002) - and weight. The initial physiological stage is that of maintenance; that is, in this stage, ewes have not yet started body development, gained weight or reached the reproductive phase. After the initial attributions, the model is able to identify low BCS ewes, redirecting them to flushing for 30 days, with $300 \mathrm{~g}$ concentrate.animal.day-1 (16\% crude protein, CP; $74 \%$ total digestible nutrients, TDN, in dry matter). After flushing, all ewes are bred.

Ewes showing positive pregnancies were attributed to a gestational period and went into delay, that is, a 120-day standby mode from the beginning of the breeding season. After the delay, ewes were given supplement feed ( $800 \mathrm{~g}$ concentrate $+2.4 \mathrm{~kg}$ corn silage.animal.day-1) until they reached 150 days of gestation, counted individually from the date of breeding to the lambing period, maintaining the supplementation until 15 days postpartum. At this phase, the ewe may or may not have developed gestational toxemia and concomitant abortion or death. According to the statistical database findings, another Famacha score has also been attributed to pregnant mothers. Ewes showing high Famacha scores compute additional costs with vermifuge and were attributed a high Famacha score marker, which, if kept high during lactation, served as a criterion for ewe culling at the end of the year.

During lambing, the probabilities of care, ewe death, mastitis development and eventual non-lambing were attributed. For lambing ewes, the "in lactation" attribute was added, and the number of lambs born (simple - one lamb, or twin - two lambs), as well as the sex of lambs, were determined. At this stage, lambs were attributed a birth weight according to the type of lambing and sex (male or female). Then, the model assorted the possibility of stillborn lamb occurrence. Each lamb corresponded to a new temporary agent in the system, which was included in the model flowchart separately from the ewe. For each lamb born, the probability of death within the first five days of life was drawn.

The first clostridiosis vaccine dose was administered to lambs when they were 30 days old and reinforced at 60 days of age. Suckling lambs' average daily gain (ADG) was checked until they reached $18 \mathrm{~kg}$; at this stage, lamb ADG is consistent with the termination phase. All male lambs were destined for slaughter and were weighed daily to check whether they had reached an adequate slaughter weight. Ewe lambs, in turn, were kept in the termination phase until they reached slaughter weight; however, the required number of replacement ewe lambs was verified before the surplus could be slaughtered. Replacement ewe lambs were considered lambs and were directed to another ADG loop, where they remained until they reached $70 \%$ of the adult body weight - a condition recommended by the LAPOC/UFPR so that ewe lambs can mate.

After the lamb termination period, mothers entered a maintenance stage until the next reproductive cycle. By the end of the year, all ewes and ewe lambs were in the maintenance phase. Before the next mating season, ewes older than six years, cases of consecutive infertility, persistent high Famacha scores, and mastitis and abortion history were checked. If the ewe was positive for any of these, the ewe was discarded and left the herd, with its costs and value calculated. 


\section{Macrothink}

Macro information - still within the design stage - includes fundamental facts, information and statistics obtained from observation, personal experience or historical archives (De Freitas Filho, 2008). This information feeds the models and is an important step prior to the implementation phase. The model was devised for a 30-hectare (ha) farm with a Tifton-85 (Cynodon sp.) and ryegrass (Lolium multiflorum Lam.) continuous grazing system, with a $12 \%$ body weight (BW) supply of green fodder.day-1, and lambs remaining with the dams until slaughter, on pasture. According to the experiments already carried out by LAPOC/UFPR (Stivari, 2012), the physical limit of a pasture termination system would support approximately 400 ewes and their respective lambs during the lamb termination peak. This figure refers to a representative herd for the region and is in accordance with those proposed by Stott et al. (2005) and Toro-Mujica et al. (2011). Tables 1 to 3 summarises the model inputs and sources of origin, whether the information came from the LAPOC/UFPR database, the literature or was determined on an ad hoc basis.

Table 1. Agents and temporary agents of hybrid simulation model herd, using agent-based and discrete event simulation, from a sheep production system.

\begin{tabular}{c|c|l|l|c}
\hline Component & Classification & \multicolumn{1}{|c|}{ Description } & Input parameters & Data source \\
\hline Ewe & Agent & Adult female sheep & $\begin{array}{l}\text { Two to six years of } \\
\text { age }\end{array}$ & LAPOC/UFPR \\
\hline Female lamb & Temporary agent & $\begin{array}{l}\text { Young female sheep. } \\
\text { Remains in this category } \\
\text { until reaching 70\% of live } \\
\text { weight of an adult or two } \\
\text { years old }\end{array}$ & $\begin{array}{l}\text { Toung female sheep. } \\
\text { Classification rording to herd size } \\
\text { destined to herd } \\
\text { replacement or meat } \\
\text { production }\end{array}$ & Ad hoc \\
\hline Male lamb & Temporary agent & $\begin{array}{l}\text { Young male sheep. Raised } \\
\text { for meat production }\end{array}$ & Ad hoc \\
\hline Ram & Agent & Adult male sheep & $\begin{array}{l}\text { Ratio of 1 male to } \\
\text { each set of 50 } \\
\text { sheep }\end{array}$ & LAPOC/UFPR \\
\hline
\end{tabular}


Table 2. Variables of hybrid simulation model herd from a sheep production system

\begin{tabular}{|c|c|c|c|c|}
\hline Component & Classification & Description & Input parameters & Data source \\
\hline Age & Variable & $\begin{array}{l}\text { Physiological } \\
\text { age of animals }\end{array}$ & $\begin{array}{l}\text { Lamb (a): < } 150 \text { days; ewe lamb: } 151 \\
\text { days to } 2 \text { years; ewe: } 2 \text { to } 6 \text { years }\end{array}$ & $\begin{array}{c}\text { LAPOC/UFPR and } \\
\text { Ad hoc }\end{array}$ \\
\hline Weight & Variable & $\begin{array}{l}\text { Live weight in } \\
\text { kilograms }\end{array}$ & $\begin{array}{l}\text { Lambs for slaughter: } 40 \mathrm{~kg} \text {; ewe lambs: } \\
32 \text { to } 58 \mathrm{~kg} ; \text { ewes: } \mathrm{TRI}^{\mathrm{a}} \quad(62.000 \text {; } \\
105.140 ; 83.883) \mathrm{kg}\end{array}$ & LAPOC/UFPR \\
\hline Carcass yield & Variable & $\begin{array}{l}\text { Average carcass } \\
\text { weight yield } \\
(\%)\end{array}$ & $\mathrm{TRI}^{\mathrm{a}}(41.3 ; 47.5 ; 46.9)$ & LAPOC/UFPR \\
\hline \multirow{4}{*}{$\begin{array}{l}\text { Famacha and } \\
\text { Body } \\
\text { Condition } \\
\text { Score (BCS) }\end{array}$} & \multirow{4}{*}{ Variable } & \multirow{4}{*}{$\begin{array}{lr}\text { Famacha } & - \\
\text { score } & \text { for } \\
\text { parasitic } & \\
\text { infection; BCS } \\
\text { - method to } \\
\text { evaluate the } \\
\text { animal body } \\
\text { condition. } \\
\text { These vary } \\
\text { according to the } \\
\text { physiological } \\
\text { period }\end{array}$} & LFLB - Low Famacha and low BCS; & \multirow{4}{*}{ LAPOC/UFPR } \\
\hline & & & LFHB - Low Famacha and high BCS; & \\
\hline & & & HFLB - High Famacha and low BCS; & \\
\hline & & & $\begin{array}{l}\text { HFHB - High Famacha alto and high } \\
\text { BCS }\end{array}$ & \\
\hline \multirow{4}{*}{$\begin{array}{l}\text { Average Daily } \\
\text { Gain (ADG) }\end{array}$} & \multirow{4}{*}{ Variable } & \multirow{4}{*}{$\begin{array}{l}\text { Animal average } \\
\text { live weight gain } \\
\text { (kg) per day }\end{array}$} & Ewe lamb: 0.110 kg.day ${ }^{-1}$; & \multirow{4}{*}{ LAPOC/UFPR } \\
\hline & & & $\begin{array}{l}\text { Female lamb-lactation: Single lambing: } \\
0.281 \mathrm{~kg}^{-} \mathrm{day}^{-1} \text {; Twin lambing: } 0.227 \\
\text { kg.day }^{-1} \text {; }\end{array}$ & \\
\hline & & & $\begin{array}{l}\text { Male lamb - lactation: Single lambing: } \\
0.311 \mathrm{~kg} \cdot \text { day }^{-1} \text {; Twin lambing: } 0.238 \\
\text { kg.day }^{-1} \text {; }\end{array}$ & \\
\hline & & & $\begin{array}{l}\text { Male/Female lambs up to slaughter: } \\
0.230 \text { kg.day }^{-1} \text {. }\end{array}$ & \\
\hline \multirow{2}{*}{$\begin{array}{l}\text { Numbers of } \\
\text { lambs per } \\
\text { lambing }\end{array}$} & \multirow[t]{2}{*}{ Variable } & \multirow{2}{*}{$\begin{array}{l}\text { Number of } \\
\text { lambs born per } \\
\text { lambing. }\end{array}$} & Ewe: Single $-46 \%$; Twin $-54 \%$; & \multirow[t]{2}{*}{ LAPOC/UFPR } \\
\hline & & & Ewe lamb: Single $-84 \%$; Twin $-16 \%$. & \\
\hline Sex & Variable & $\begin{array}{l}\text { Probability of } \\
\text { male or female } \\
\text { lamb birth }\end{array}$ & $50 \%$ female; $50 \%$ male & LAPOC/UFPR \\
\hline \multirow{2}{*}{ Birth weight } & \multirow{2}{*}{ Variable } & \multirow{2}{*}{$\begin{array}{l}\text { Lamb weight at } \\
\text { birth varies } \\
\text { according to sex } \\
\text { and number of } \\
\text { lambs per } \\
\text { lambing }\end{array}$} & $\begin{array}{l}\text { Female lambs. Single: NOR.tr }{ }^{\mathrm{b}} \text { (5.370; } \\
0.923 ; 3.140 ; 7.250) ; \quad \text { Twin: NOR.tr } \\
(4.345 ; 0.850 ; 2.165 ; 6.600) ;\end{array}$ & \multirow{2}{*}{ LAPOC/UFPR } \\
\hline & & & $\begin{array}{l}\text { Male lambs. Single: NOR.tr }(5.955 \text {; } \\
1.068 ; 2.950 ; 8.600) ; \quad \text { Twin: } \\
(4.697 ; 0.948 ; 2.110 ; 7.100) .\end{array}$ & \\
\hline Assistance & Variable & $\begin{array}{l}\text { Intervention } \\
\text { during lambing }\end{array}$ & $10 \%$ & Ad hoc \\
\hline Mating rate & Variable & $\begin{array}{l}\text { Number of } \\
\text { mated females } \\
\text { in relation to } \\
\text { number of } \\
\text { females } \\
\text { exposed to } \\
\text { mating } \\
\end{array}$ & Ewes: $89 \%$; ewe lambs: $79 \%$. & LAPOC/UFPR \\
\hline Abortion rate & Variable & $\begin{array}{l}\text { Number of } \\
\text { females that } \\
\text { aborted }\end{array}$ & $2 \%$ & Literature \\
\hline Still births & Variable & $\begin{array}{l}\text { Stillborn or } \\
\text { lambs that died } \\
\text { at birth }\end{array}$ & $4 \%$ & LAPOC/UFPR \\
\hline $\begin{array}{l}\text { Neonatal } \\
\text { mortality }\end{array}$ & Variable & $\begin{array}{l}\text { Lamb mortality } \\
\text { until five days } \\
\text { of life }\end{array}$ & $3 \%$; assisted: $2.6 \%$; mastitis: $15 \%$. & $\begin{array}{l}\text { LAPOC/UFPR } \\
\text { and Literature }\end{array}$ \\
\hline $\begin{array}{l}\text { Mortality at } \\
\text { lactation }\end{array}$ & Variable & $\begin{array}{l}\text { Lamb mortality } \\
\text { at lactation }\end{array}$ & 4\%; mastitis: $20 \%$. & $\begin{array}{l}\text { LAPOC/UFPR } \\
\text { and Literature }\end{array}$ \\
\hline Mortality at & Variable & Lamb mortality & $1 \%$ & Ad hoc \\
\hline
\end{tabular}




\begin{tabular}{|c|c|c|c|c|}
\hline termination & & at termination & & \\
\hline \multirow[t]{2}{*}{ Ewe mortality } & \multirow[t]{2}{*}{ Variable } & \multirow{2}{*}{$\begin{array}{l}\text { Adult female } \\
\text { sheep mortality. } \\
\text { Varies } \\
\text { according to } \\
\text { physiological } \\
\text { period and } \\
\text { event } \\
\text { occurrence }\end{array}$} & $\begin{array}{l}\text { Maintenance: } 4 \% \text {; assisted lambing: } \\
10 \% \text {; }\end{array}$ & \multirow{2}{*}{$\begin{array}{l}\text { LAPOC/UFPR and } \\
\text { Ad hoc }\end{array}$} \\
\hline & & & toxemia: $100 \%$. & \\
\hline $\begin{array}{l}\text { Pregnancy } \\
\text { toxemia }\end{array}$ & Variable & $\begin{array}{l}\text { Metabolic } \\
\text { disease } \\
\text { affecting sheep } \\
\text { during the final } \\
\text { third of } \\
\text { gestation }\end{array}$ & $1 \%$ & Ad hoc \\
\hline Mastitis & Variable & $\begin{array}{l}\text { Inflammation of } \\
\text { the mammary } \\
\text { gland }\end{array}$ & $0.5 \%$ & LAPOC/UFPR \\
\hline Fertility rate & Variable & $\begin{array}{ll}\text { Number } & \text { of } \\
\text { pregnant } & \\
\text { females } & \text { in } \\
\text { relation } & \text { to } \\
\text { number } & \text { of } \\
\text { females } & \\
\text { exposed } & \text { to } \\
\text { mating } & \end{array}$ & Ewes: $93 \%$; ewe lambs: $81 \%$. & LAPOC/UFPR \\
\hline
\end{tabular}

aTRI: Triangular distribution (minimum, maximum, mode); bNOR.tr: Trimmed normal distribution (mean, standard deviation, minimum, maximum)

Table 3. Process in a hybrid simulation model herd from a sheep production system

\begin{tabular}{|c|c|c|c|c|}
\hline Component & Classification & Description & Input parameters & Data source \\
\hline Flushing & Process & 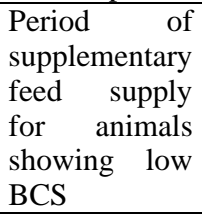 & 30 days & LAPOC/UFPR \\
\hline Mating & Process & $\begin{array}{l}\text { Reproductive } \\
\text { period of ewes } \\
\text { and rams }\end{array}$ & 45 days & LAPOC/UFPR \\
\hline Mating return & Process & $\begin{array}{l}\text { Additional } \\
\text { reproductive } \\
\text { period of ewes } \\
\text { and rams }\end{array}$ & 15 days & LAPOC/UFPR \\
\hline $\begin{array}{l}\text { Gestation } \\
\text { diagnosis }\end{array}$ & Process & $\begin{array}{l}\text { Gestational } \\
\text { diagnosis of } \\
\text { ewes that were } \\
\text { lambed during } \\
\text { mating and } \\
\text { mating return } \\
\end{array}$ & $\begin{array}{l}30 \text { days after end } \\
\text { of mating return } \\
\text { period }\end{array}$ & LAPOC/UFPR \\
\hline Birth & Process & Lambing & $\begin{array}{|lr|}150 \text { days } & \text { after } \\
\text { mating } & \text { date } \\
\text { performed } & \\
\text { during } & \text { the } \\
\text { mating } & \text { or } \\
\text { mating } & \text { return } \\
\text { period } & \\
\end{array}$ & LAPOC/UFPR \\
\hline Slaughter & Process & $\begin{array}{l}\text { Slaughter of } \\
\text { male or } \\
\text { female lambs } \\
\text { for meat } \\
\text { production }\end{array}$ & $\begin{array}{|lr|}\text { Slaughter of } \\
\text { animals that } \\
\text { reached the } \\
\text { slaughter weight } \\
\text { or that were } 150 \\
\text { days old }\end{array}$ & Ad hoc \\
\hline
\end{tabular}

The economic financial analyses of the model were based on Stivari's proposal (2012) due to 
data similarity. All prices were those charged in 2015, obtained by consulting the list of prices paid to producers by the Agriculture and Supply Department of Paraná State, Brazil (SEAB-PR, 2016), as well as by means of market surveys, when not included in the database. All figures were adjusted to the inflation rate for the month of December 2015 by using the Consumer Price Index calculated by the Brazilian Institute of Geography and Statistics (IBGE, 2016). Exchange rate for December 2015: USD $1.00=\mathrm{R} \$ 3.8705$, according to Brazilian Central Bank (BCB, 2016).

An inventory of the necessary improvements and machinery was prepared, including a $50 \mathrm{~m}^{2}$ warehouse, a $400 \mathrm{~m}^{2}$ sheepfold for shelter during the pre and post-lambing seasons, and wire mesh fences in the paddock perimeter. Machinery and equipment included a hand grass cutter, an animal weighing scale, a feed mixer, a refrigerator and a cart. The total capital asset in buildings, facilities machinery and equipment was $\mathrm{R} \$ 121477.52$.

For conservation and repair calculation purposes, $2 \%$ of the value of the new asset per year was considered; for the warehouse and sheepfold, $15 \%$ per year for fences, and $10 \%$ per year for the refrigerator, feed mixer, scales, cutter and cart were considered. Depreciation was obtained by the linear method (Croitoru et al., 2015), with a $10 \%$ residual value of the new assets for machinery and equipment, $20 \%$ for the warehouse and forage, and $0 \%$ for the fence. The service life was 30 years for the sheepfold and warehouse, 15 years for the fences, feeder, salt lick, water bunk, feed mixer, refrigerator and cart, and 5 years for the cutter and scale.

Concentrate was prepared on the farm and its costs were accounted. The concentrate was composed of corn grain and meal, soybean meal and hulls, wheat meal, mineral supplement, limestone, ammonium chloride and urea. Expenditures on pasture implementation and management were accounted for according to a model proposed by INSTITUTO FNP, (2010) and LAPOC/UFPR practices. The costs of cleaning and hygiene materials, medicines, vaccines and antiparasitics were calculated based on LAPOC/UFPR annual consumption. The antiparasitic drug computation was in agreement with that of Salgado (2011) during the field experimental phase.

The costs for transportation and animal slaughter, technical assistance $(60 \%$ of the regional minimum wage), permanent labour of an employee who was paid a monthly regional minimum wage at the time ( $\mathrm{R} \$ 788.00$ ), in addition to labour costs of $45.59 \%$ on the annual total $(\mathrm{CONAB}, 2010)$ and working capital interest were accounted for. Working capital interest costs were based on an average variable cost of $\mathrm{R} \$ 10000.00$, at a $1.89 \%$ nominal interest rate per month used by the Federal Savings Bank to guide consumer credit loan funds. Taxes on total income were: National Social Security Institute (INSS) at a rate of $2.3 \%$ on the revenues obtained from the sale of animals, and $1 \%$ for varied fees, such as association and union obligations. Brazilian Excise Tax (ICMS) was calculated at a rate of $7 \%$ on the revenue obtained from the sale of meat (Brasil, 2007).

Cost items were grouped into the following categories: variable costs, fixed costs and opportunity cost of invested capital. Variable costs (VC) are those that change according to the amount produced and whose duration is shorter than or equal to the production cycle. Fixed Costs (FC) are those that do not vary along with the amount produced, and which last 
longer than a production cycle. Maintenance, machinery and equipment depreciation costs are also considered FC (Table 4). When variable costs are added to fixed costs, the operating cost (OPC) is obtained.

Table 4. Hybrid simulation model of the production cost inputs of a sheep production system

\begin{tabular}{|c|c|c|c|c|c|}
\hline & Item & Period & Unit & Value & Description \\
\hline \multicolumn{6}{|c|}{1 - Variable costs } \\
\hline a) & Flushing & Flushing & $\mathrm{R} \$$. ewe $^{-1}$ & 0.21 & $\begin{array}{l}\text { Provided for ewes with low } \\
\text { body condition score in the } \\
\text { pre-mating period for } 30 \text { days }\end{array}$ \\
\hline b) & Supplementation & $\begin{array}{l}\text { Gestation and } \\
\text { lactation }\end{array}$ & $\mathrm{R} \$ . \mathrm{ewe}^{-1}$ & 1.63 & $\begin{array}{l}\text { Provided to ewes in the last } \\
\text { third of pregnancy for } 30 \text { days } \\
\text { and } 15 \text { days postpartum }\end{array}$ \\
\hline c) & Anthelmintic & $\begin{array}{l}\text { Maintenance, } \\
\text { gestation and } \\
\text { lactation }\end{array}$ & $\mathrm{R} \$ . \mathrm{mL}^{-1}$ & 0.33 & $\begin{array}{l}\text { Anthelmintic dose }(1 \mathrm{~mL} / 25 \\
\mathrm{kg}) \times \text { ewe weight. } \\
\text { Administered to ewes showing } \\
\text { high Famacha scores. }\end{array}$ \\
\hline d) & Clostridiosis vaccine & $\begin{array}{l}\text { Gestation and } \\
\text { lactation }\end{array}$ & $\mathrm{R} \$$.animal ${ }^{-1}$ & 0.83 & $\begin{array}{l}\text { Ewes are vaccinated } 30 \text { days } \\
\text { before lambing. Lambs are } \\
\text { given doses at } 30 \text { and } 60 \text { days } \\
\text { of age }\end{array}$ \\
\hline e) & Animal identification & Maintenance & $\mathrm{R} \$$.animal ${ }^{-1}$ & 1.50 & $\begin{array}{l}\text { Identification of replacement } \\
\text { female lambs }\end{array}$ \\
\hline f) & Slaughter & Termination & $\mathrm{R} \$$.animal ${ }^{-1}$ & 19.00 & $\begin{array}{l}\text { Transport + slaughter rate } \\
\text { GPS/INSS }(2.3 \%)+\text { Funrural }\end{array}$ \\
\hline g) & Taxes & Termination & Revenue $\%$ & 10.30 & $\begin{array}{l}(1 \%)+\operatorname{ICMS}(7 \%) \times \text { amount } \\
\text { of meat marketed } \times \text { price paid } \\
\text { per kg of meat }\end{array}$ \\
\hline \multicolumn{6}{|c|}{$2-$ Fixed costs } \\
\hline h) & Pasture management & Annual & $\mathrm{R} \$$. year $^{-1}$ & 10999.02 & $\begin{array}{l}\text { Mowing, fertilisation and } \\
\text { sowing }\end{array}$ \\
\hline i) & $\begin{array}{l}\text { Permanent labour } \\
\text { force }\end{array}$ & Annual & $\mathrm{R} \$ . y^{2} a r^{-1}$ & 9814.38 & Minimum wage + labour costs \\
\hline j) & Technical assistance & Annual & $\mathrm{R} \$$.year ${ }^{-1}$ & 2836.80 & $\begin{array}{l}\text { Fees corresponding to six } \\
\text { technical visits a year. }\end{array}$ \\
\hline k) & Medication & Annual & $\mathrm{R} \$ . y^{2} \mathrm{r}^{-1}$ & 1800.00 & $\begin{array}{l}\text { Drugs, hygiene and cleaning } \\
\text { materials }\end{array}$ \\
\hline 1) & Electricity & Annual & $\mathrm{R} \$ . y_{e a r}^{-1}$ & 240.00 & $\begin{array}{l}\text { Average annual consumption } \\
\text { for feed production }\end{array}$ \\
\hline m) & Maintenance & Annual & $\mathrm{R} \$$. year $^{-1}$ & 7232.09 & $\begin{array}{l}\text { Betterments, machinery and } \\
\text { equipment }\end{array}$ \\
\hline n) & Depreciation & Annual & $\mathrm{R} \$$.year ${ }^{-1}$ & 613486 & Betterments, machinery and \\
\hline \multicolumn{6}{|c|}{3 - Opportunity cost of fixed capital } \\
\hline p) & $\begin{array}{l}\text { Opportunity cost of } \\
\text { invested capital }\end{array}$ & Annual & $\mathrm{R} \$$.year ${ }^{-1}$ & 167285.59 & $\begin{array}{l}\text { Production factor income: } \\
\text { betterments, machinery, } \\
\text { equipment, herd and capital }\end{array}$ \\
\hline \multicolumn{6}{|c|}{ 4-Revenue } \\
\hline q) & Mutton price & Termination & $\mathrm{R} \$ . \mathrm{kg}^{-1}$ & 5.00 & Adult animal meat \\
\hline r) & Carcass price & Termination & $\mathrm{R} \$ . \mathrm{kg}^{-1}$ & 17.00 & Lamb meat \\
\hline
\end{tabular}

The invested capital cost represents an opportunity abdicated by the producer upon failing to apply the same amount of resources to another activity. In practice, the basis for the opportunity cost of capital comparisons is traditional financial market investments, such as savings accounts and commodity funds. In order to determine the opportunity cost of fixed assets, a $0.5 \%$ monthly market interest rate (reference value adopted by the savings account) on the total amount of capital invested in betterments, machinery, equipment, herd and capital was used. The total cost of production (TC) was the sum of the OPC and the opportunity cost of fixed capital. 
Sale prices were established based on those charged in Curitiba, in the state of Paraná area. Total revenue (TR) consisted of the sale of lamb and adult (mutton) meat. Table 4 shows the model cost inputs, the period they refer to, their value and brief descriptions.

A Profit and Loss Statement (PLS) was prepared for one production year, and the unit cost to produce one kilogram of lamb carcass, the operating cost per ewe, gross margin (GM, total revenue minus variable costs), net margin ( $\mathrm{NM}$, total revenue minus total cost), net operating margin (NOM, total revenue minus operating costs), total breakeven points (BEP, total cost divided by revenue) and operating breakeven (OBE, operational cost divided by revenue) were calculated. Margin (GM, NM and NOP), BEP and cost (VC, FC and OPC) calculations were performed using a simulation model developed by the AnyLogic software.

\section{Implementation process}

The second major step - is the conceptual model codification into an appropriate simulation language (Chwif \& Medina, 2014), which then needs to be checked and validated. Checking implies verifying whether a series of assumptions and simplifications of the real system were correctly implemented in the model (De Freitas Filho, 2008). Validation, on the other hand, is the process by which one seeks to accurately estimate the parameters based on field data (Manevski et al., 2016). If the outputs are considered inconsistent, the model must be checked against the available data; if discrepancies remain, the model should be modified (Manevski et al., 2016; Martin et al., 2011).

Pidd, (1996) and Sargent, (2010) state that consulting an expert is the best and simplest way to perform validation, while De Freitas Filho (2008) adds that this process, in practice, should be initiated in the design phase and extended up to the experimentation stage. Kabir et al. (2018) used a similar method of parameterisation and validation. Thus, the model presented in this study was developed based on this premise, and routine consultations were made with specialists in the area, thus validating the model.

The model was checked by means of the variance calculation (difference between the results of simulated and real scenarios, divided by the result of the real scenario) of the variables related to ewes, lambs and the economic results. The hybrid simulation model was associated with both input and output data.

\section{Analysis}

As the last step of the method, the simulation model was defined as "non-terminal"; that is, an exact termination time was not set, as what really matters is the development of the study within the period in which the simulation is permanent (Chwif \& Medina, 2014). Thus, a seven-year warm-up was performed such that there were ewes of all ages up to culling age, making a stabilised and active herd. An analysis of the results was computed after the warm-up period.

The scenarios involved a productive cycle and an independent mode, which is one in which changing one variable does not imply the systemic alteration of another variable. For each scenario, a parameter variation amplitude was established and sensitivity analyses were performed using the regression method (Table 5). 
Table 5. Range of variation of sensitivity analyses for the experiments and scenarios studied in the hybrid simulation model

\begin{tabular}{|c|c|c|c|c|}
\hline \multicolumn{2}{|c|}{ Scenario } & Description & Original values & Range of variation \\
\hline $\mathrm{S} 1$ & \multirow{5}{*}{$\begin{array}{l}\text { Ewe and } \\
\text { ewe lamb }\end{array}$} & $\begin{array}{l}\text { Increase/decrease } \\
\text { in mating rate }\end{array}$ & $\begin{array}{l}\text { Ewes: } 89 \% \\
\text { Ewe lambs: } 79 \%\end{array}$ & $\pm 10 \mathrm{pp}^{\mathrm{a}}$, varying for each $1 \mathrm{pp}$ \\
\hline $\mathrm{S} 2$ & & $\begin{array}{l}\text { Increase/decrease } \\
\text { in fertility rate }\end{array}$ & $\begin{array}{l}\text { Ewes: } 93 \% \\
\text { Ewe lambs: } 81 \%\end{array}$ & $\pm 10 \mathrm{pp}$, varying for each $1 \mathrm{pp}$ \\
\hline $\mathrm{S} 3$ & & $\begin{array}{l}\text { Increase/decrease } \\
\text { in male:female } \\
\text { ratio }\end{array}$ & $1: 50$ & $\begin{array}{l}1: 50 \text { to } 1: 400 \text {, varying for every } \\
20 \text { ewes }\end{array}$ \\
\hline S4 & & $\begin{array}{l}\text { Increase/decrease } \\
\text { in single lambing } \\
\text { incidence }\end{array}$ & $\begin{array}{l}\text { Ewes: } 46 \% \\
\text { Ewe lambs: } 84 \%\end{array}$ & $\begin{array}{l} \pm 50 \mathrm{pp} \text {, varying for every } 5 \mathrm{pp} \text {. } \\
\text { Ewe lambs do no change }\end{array}$ \\
\hline S5 & & $\begin{array}{l}\text { Increase/decrease } \\
\text { in abortion } \\
\text { incidence }\end{array}$ & $2 \%$ & $\pm 20 \mathrm{pp}$, varying for each $1 \mathrm{pp}$ \\
\hline S6 & \multirow{4}{*}{ Lamb } & $\begin{array}{l}\text { Increase/decrease } \\
\text { in stillbirth rate }\end{array}$ & $4 \%$ & $\pm 15 \mathrm{pp}$, varying for each $1 \mathrm{pp}$ \\
\hline S7 & & $\begin{array}{l}\text { Increase/decrease } \\
\text { in neonatal } \\
\text { mortality rate }\end{array}$ & \begin{tabular}{l}
\multicolumn{3}{l}{ Eutocic lambing: $3 \%$} \\
Assisted lambing: \\
$2.6 \%$ \\
Ewe with mastitis: \\
$15 \%$
\end{tabular} & $\pm 20 \mathrm{pp}$, varying for each $1 \mathrm{pp}$ \\
\hline S8 & & $\begin{array}{l}\text { Increase/decrease } \\
\text { in lactation } \\
\text { mortality rate }\end{array}$ & $\begin{array}{l}4 \% \\
\text { Ewes with mastitis: } \\
20 \%\end{array}$ & $\pm 15 \mathrm{pp}$, varying for each $1 \mathrm{pp}$ \\
\hline S9 & & $\begin{array}{l}\text { Increase/decrease } \\
\text { in termination } \\
\text { mortality rate }\end{array}$ & $1 \%$ & $\pm 20 \mathrm{pp}$, varying for each $1 \mathrm{pp}$ \\
\hline S10 & \multirow{3}{*}{$\underset{\mathrm{nt}}{\text { Manageme }}$} & $\begin{array}{l}\text { No culling of ewes } \\
\text { over six years of } \\
\text { age }\end{array}$ & Age $>6$ years & No culling \\
\hline S11 & & $\begin{array}{l}\text { No culling of } \\
\text { infertile ewes }\end{array}$ & $\begin{array}{l}\text { Infertility }>2 \text { years in } \\
\text { a row }\end{array}$ & No culling. \\
\hline S12 & & $\begin{array}{l}\text { Increase/decrease } \\
\text { in average daily } \\
\text { gain }\end{array}$ & $0.230 \mathrm{~kg} \mathrm{day}^{-1}$ & $\begin{array}{l}\text { Variation between } 0.180 \text { and } \\
0.370 \mathrm{~kg}^{-d a y^{-1}} \text {, varying for each } \\
0.010 \mathrm{~kg}^{-d_{a y}{ }^{-1}} \text {. }\end{array}$ \\
\hline
\end{tabular}

app: percentage points; S1 to S5: scenarios referring to changes in the productive parameters of ewes and ewe lambs: S6 to S9: scenarios referring to changes in the productive parameters of lambs; S10 to S12: scenarios referring to changes in herd management criteria

According to De Freitas Filho (2008), as a rule, the collection of data to produce a sample from a model simulation can be performed in two ways: by making use of individual observations within each replication, or by performing simulations (replications). In this study, the second option was chosen, and 100 replications were performed for each scenario.

\section{Results}

The financial year net result simulation average was $\mathrm{R} \$-3803.27$, with a standard deviation of $\mathrm{R} \$ 3389.19$, and with limit values ranging from $\mathrm{R} \$-13475.80$ to $\mathrm{R} \$ 3$ 055.40. The net operational margin (NOM) showed positive financial results, with values between $\mathrm{R} \$ 11$ 741.80 and $R \$ 21389.80$, and an average of $R \$ 14412.14 \pm R \$ 3873.02$ (Table 6). 


\section{Macrothink}

Journal of Agricultural Studies

ISSN 2166-0379

2019, Vol. 7, No. 3

Table 6. Production year profit and loss statement in a simulated meat sheep production system

\begin{tabular}{lr}
\hline \multicolumn{1}{c}{ Profit and loss statement ${ }^{\mathrm{a}}$} & $\mathrm{R} \$ . \mathrm{year}^{-1}$ \\
\hline Gross operating revenue & \\
Lamb meat sales & 73233.24 \\
Culling ewe sales & 14080.27 \\
(-) Gross revenue deductions & \\
$\quad$ Taxes & 8993.29 \\
Net operating revenue & 78320.22 \\
(-) Sales costs & \\
Slaughter costs & 5208.66 \\
Feed costs & 18488.46 \\
Health costs & 815.54 \\
Gross operating results & 53807.56 \\
(-) Operating expenses & \\
Permanent labour costs & 9814.38 \\
Pasture management costs & 10999.02 \\
Technical assistance costs & 2836.80 \\
Drug costs & 1800.00 \\
Electricity costs & 240.00 \\
Maintenance costs & 7232.09 \\
Depreciation costs & 6134.86 \\
Working capital interest costs & 338.27 \\
Financial year net result & 14412.14 \\
\hline
\end{tabular}

${ }^{a}$ Average of 100 replications; Exchange rate for December 2015: USD 1.00 = R $\$ 3.8705$, according to $\mathrm{BCB}$

Food had the greatest net profit impact $(25.4 \%)$ in the yearly profit and loss statement, followed by pasture management $(15.1 \%)$, permanent labour (13.5\%) and taxes $(12.3 \%)$.

Health costs were relatively low $(1.3 \%)$ in relation to operating costs. This low percentage can be attributed to the distribution of animals with lower Famacha scores, where the average simulated by the model was 292 cases, that is, one vermifugation for each 0.73 sheep.year- 1 (400 ewes and ewe lambs).

When the economic results of the model were analysed, the productive system was found to have operated profitably; that is, the operating breakeven point (BEP) was obtained before $100 \%$, with a surplus over operating costs. The average number of slaughtered lambs verified by the model was in 240 animals, with a minimum of 199 and a maximum of 291 animals under the patterned parameters, and an average slaughter rate of $68.4 \pm 3.9 \%$. However, when 
calculations included the total cost of production, the BEP exceeded $100 \%$, i.e. production was not sufficient to compensate for all production costs, even with a slaughter rate close to $70 \%$ of production. The average production operating cost per kilogram of marketed carcass was $\mathrm{R} \$ 13.77$, having reached an operational balance at $84.1 \%$ of production.

When analysing the proposed ewe-related variable scenarios (scenarios S1 to S5) in relation to the slaughter rate, a greater linear response was observed for the abortion rate, with the fertility rate being another important component (Table 7). In the scenarios referring to lamb-related variables (S6 to S9), a greater linear response was observed for the termination and neonatal mortality rate, as described in Table 7.

Table 7. Analysis of proposed scenarios in relation to ewe (S1 to S5) and lamb (S6 to S9 and S12) slaughter rate variables

\begin{tabular}{clrrr}
\hline Scenario & \multicolumn{1}{c}{ Equation } & $\mathrm{R}^{2 *}(\%)$ & $t(\mathrm{a})$ & $t(\mathrm{x})$ \\
\hline S1 & Slaughter rate $(\%)=0.4793+0.2365 *$ mating rate & 89.5 & 32.3 & 13.4 \\
S2 & Slaughter rate $(\%)=0.4410+0.2592 *$ fertility rate & 92.5 & 29.7 & 15.7 \\
S3 & Slaughter rate $(\%)=0.6960-0.0002 *$ male:female ratio & 61.5 & 70.5 & -5.6 \\
S4 & Slaughter rate $(\%)=0.7136-0.0008 *$ single lambing & 95.1 & 288.9 & -20.2 \\
S5 & Slaughter rate $(\%)=0.6949-0.7731 *$ abortion & 99.1 & 351.7 & -50.2 \\
S6 & Slaughter rate $(\%)=0.7148-0.8697 *$ stillborns & 99.4 & 436.9 & -59.0 \\
S7 & Slaughter rate $(\%)=0.7255-1.5931 *$ neonatal mortality & 99.5 & 232.1 & -68.4 \\
S8 & Slaughter rate $(\%)=0.7154-0.8827 *$ lactation mortality & 99.2 & 269.2 & -50.6 \\
S9 & Slaughter rate $(\%)=0.6894-0.8507 *$ termination mortality & 99.6 & 480.3 & -72.7 \\
S12 & Slaughter rate $(\%)=0.6599+0.0917 *$ average daily gain & 72.4 & 182.8 & 7.1 \\
\hline
\end{tabular}

S1 evaluates changes in ewe mating rates; S2 evaluates changes in ewe fertility rates; S3 evaluates changes in the male:female ratio; $\mathrm{S} 4$ evaluates changes in the incidence of single births; S5 evaluates abortion rate changes; S6 evaluates changes in stillborn lamb rates; S7 evaluates changes in neonatal mortality rates; S8 evaluates changes in mortality rates in the lactation period; S9 evaluates changes in mortality rates at termination; S12 evaluates changes in lamb average daily gain. $* \mathrm{R}^{2}$-adjusted; $\mathrm{T}$ : Student's t-test.

Upon analysing ewe performance, the abortion rate showed a higher linear response, as contrasted to the birth rate (birth rate $=1.0992-1.2848 *$ abortion, adjusted coefficient of determination $\left.\mathrm{R}^{2}=99.7 \%\right)$ and the net operating margin $(\mathrm{NOM} \mathrm{R} \$=14529.7414-59$ $672.5337 *$ abortion, adjusted coefficient of determination $\left.\mathrm{R}^{2}=95.7 \%\right)$. However, neonatal mortality had the greatest impact on NOM (NOM R\$ = $17782.2975-140473.3895 *$ neonatal mortality, adjusted $\mathrm{R}^{2}=99.6 \%$ ), and on general lamb mortality (Mortality $\%=$ $0.0965+1.74 *$ neonatal mortality, adjusted $\left.\mathrm{R}^{2}=99.2 \%\right)$.

Ewe mating failure was not attributed to male sexual performance, inasmuch as when scenario S3 was performed, alterations were only perceived when occurring in scenarios that did not correspond to reality, such as the 1:200 ratio. It is believed the ease of modeling this 
variable may have caused the loss of other information, which in turn could better explain the effect of the male and female ratio within the productive system. However, it is believed that the presence of lambs in the herd may have negatively influenced the mating rate, as data showed a $10 \%$ ewe reduction. Thus, mating rate failure occurred due to the sheep.

As for management standards, scenarios S10 and S11 (which simulated ewe culling or not according to age and/or consecutive infertility, respectively) showed a 52\% NOM increase in relation to the base scenario when culling was not performed (six years); it was economically more interesting than the slaughter of ewes due to infertility. These results can be accounted for by the fact that there was a greater number of ewes, as compared to ewe lambs, in the herd (309 and 91 versus 255 and 145 in the baseline scenario), increasing the reproductive parameter averages, such as the mating rate, fertility rate and number of multiple births, resulting in a higher number of lambs in the herd.

Reproductive trait improvement did not have a greater economic impact than that of lamb growth. Neonatal mortality was the ewe- and lamb-related variable that most affected the slaughter rate (Table 7), birth rate and NOM; that is, the main critical period for production is the first five days of lamb life.

Considering the variables that can influence the slaughter rate within the ewe performance parameters, the abortion rate was the main cause of the slaughter rate, birth rate and the NOM reduction.

\section{Discussion}

Lamb feed costs in Brazil have played a major role in the production of meat sheep (Barros et al., 2009a; Barros et al., 2009b; Paim et al., 2011; Raineri et al., 2015a; Stivari et al., 2013; Ziguer et al., 2011). Raineri et al. (2015a), upon analysing the elasticity of meat sheep production costs in a feedlot in Brazil, reported higher contribution margins (63\%) and an elastic, positive feed increase. In Turkey's provinces, Demirhan (2019), through a questionnaire, found that the main problems identified by sheep producers were the cost of feed. Thus, the adequate management of feed costs seems to be relevant for sheep production.

The significant tax contribution on sheep production in this study is in accordance with the findings of Raineri et al. (2015b), Sorio \& Rasi (2010) and Souza et al. (2008). These authors stated that informality is present in the production, slaughter, marketing and carcass processing of Brazilian sheep, in which $55 \%$ of farmers perform the slaughter and marketing on their own farms, both because of the possibility of achieving higher sales figures and evading taxes. This practice is of great concern to the Brazilian sheep industry, not only because of the exclusion of the health surveillance system, but also because of the disruption of the entire production chain.

The low herd health contribution to production costs is a reality in the LAPOC/UFPR sheep production environment, which has satisfactory standards and herd health control. Health protection programmes are sometimes understood as extra costs related to sheep production; however, an increase in lamb deaths can lead to higher losses (Demirhan, 2019). In a study carried out on representative commercial farms with respect to meat lamb production, Raineri 
et al. (2015b) noted the use of anthelmintics as one of the factors that least impacted the production costs of sheep farming, which is in agreement with our findings. It is believed that submodels, which can add information on genetic selection by resistant animals, can be more sensitive to the effects of age and differences in pasture management; therefore, the impact of the health variable could be refined, its behaviour better understood and its analysis improved.

Producers who want to obtain or modify production costs need to pay attention to the productive performance of the herd. The slaughter rate directly influences costs per kilogram of live weight, in which the production costs are inversely proportional to the slaughter rate of the herd: the higher the slaughter rate, the more kilograms of meat are marketed and the lower the costs per kilogram of meat produced (Viana \& Silveira, 2009).

Wang \& Dickerson (1991) stated that reproductive trait improvement has a greater economic impact than that of lamb growth. Although these results were not found in our research, this assumption was only observed when the effect of the average daily gain on the slaughter rate was analysed, and was unrelated to lamb mortality.

According to Simplício \& Azevedo (2014), high prolificacy selection is important because birth is associated with the survival of a large number of lambs, and because it favours the genetic improvement of the herd. Despite the results presented by these authors, the scenario results showed that a reduction in the number of single births was not a major contributor to an increase in the slaughter rate, birth rate and/or net operating margin.

Alterations to the fertility and mating rates of ewes did not result in big economic gains, as compared to the management of lambs in their first days of life. This reinforces the necessity for special attention to this phase in the production system, without neglecting the role of embryonic survival, stillbirths and postnatal mortality (Gouveia, 2006).

Knowing that the average operating cost of maintenance ewes was approximately R $\$ 136.83$ ewe.year ${ }^{-1}$, which was higher than that of $\mathrm{R} \$ 66.10$ found by Paim et al. (2011) - unmated females added approximately $\mathrm{R} \$ 64.00$ to the cost per ewe to the system - an equivalent to approximately $1355 \mathrm{~kg}$ of lamb meat, not generating an additional revenue of approximately $\mathrm{R} \$ 23000.00$. Of the mated sheep (273), 26 did not get pregnant (9.5\%), and $5 \pm 2$ sheep proved to be infertile for two consecutive years; that is, infertility caused a loss of approximately R $\$ 11000.00$ to the system.

These results are in agreement with those published by Simplício \& Azevedo (2014), who emphasised that the profitability by ewes and area unit exploration is influenced by the number of offspring marketed and incorporated into the herd as replacement animals. Bohan et al. (2018) found that the main drivers of profitability were the number of lambs weaned per ha, related to the growth and utilisation of pastures, since the animals of this simulation were also considered to be grazing.

In non-stabilised herds with health control weaknesses, an increase in the number of abortions is usually associated with outbreaks of infectious diseases, such as Toxoplasma gondii (toxoplasmosis), Chlamydia psittach (enzootic abortion) and Campylobacter fetus 
(vibriosis) (Pereira et al., 2013). When the infectious component is not the causative agent, the incidence of abortions is usually sporadic and due to blows, high stress during prepartum shearing, the administration of contraindicated drugs during the gestation period, incorrect nutritional management and fights between animals (Alves et al., 2014; Eales \& Small, 2008). These factors are closely related to a low quality workforce and technification, as well as inadequate shelter (location, size) in prepartum, which can lead to overcrowding, increasing the probability of fights between animals.

\section{Conclusions}

The simulation model identified that the reproductive characteristics were not the variables that most influenced the productive and economic results as many believe, but rather those related to the first day's life care of lamb.

The assignment of individual characteristics of the animals (the agent-based approach) and the use of a complete and detailed database provided the development of a more robust and adequate simulation model for representation of the productive system. This allows the study and analysis of different technological combinations without the need of field experiment, aiming to guide scientists' efforts towards the development of further research in animal science.

Simulation modelling can also be used as a didactic and practical tool to demonstrate the cause-effect relationships in livestock for the non-scientist public, as farmers and policymakers, for example. Similar approach can be applied for other important livestock systems.

\section{Acknowledgement}

The authors acknowledge the financial support from São Paulo Research Foundation (FAPESP project 2012/10841-0).

\section{References}

Alves, F. S. F., Ribeiro, L. A. O., \& Pinheiro, R. R. (2014). Principais enfermidades infecciosas em rebanhos ovinos brasileiros. In A. B. Selaive-Villarroel \& J. C. da S. Osório (Eds.), Produção de ovinos no Brasil. São Paulo: Roca. Retrieved March 7, 2016, from https://www.bdpa.cnptia.embrapa.br/consulta/busca?b=ad\&id=993505\&biblioteca=vazio\&bu sca=Principais enfermidades infecciosas em rebanhos ovinos brasileiros.\&qFacets=Principais enfermidades infecciosas em rebanhos ovinos brasileiros

Banks, J., \& Carson, F. S. (1984). Discrete-event system simulation. (1st ed.). Prentice-Hall.

Barros, C. S. de, Monteiro, A. L. G., Poli, C. H. E. C., Dittrich, J. R., Canziani, J. R. F., \& Fernandes, M. A. M. (2009). Rentabilidade da produção de ovinos de corte em pastagem e em confinamento. Revista Brasileira de Zootecnia, 38(11), 2270-2279. https://doi.org/10.1590/S1516-35982009001100029

Barros, C. S. de, Monteiro, A. L. G., Poli, C. H. E. C., Fernandes, M. A. M., Almeida, R. De, \& Fernandes, S. R. (2009). Resultado econômico da produção de ovinos para carne em pasto 
de azevém e confinamento. Acta Scientiarum. Animal Sciences, 31(1). https://doi.org/10.4025/actascianimsci.v31i1.3995

Barros, C. S. de. (2008). Análise econômica de sistemas de produção de ovinos para carne. Universidade Federal do Paraná.

BCB, B. C. do B. (2016). Dados históricos de taxas de câmbio. Retrieved May 20, 2016, from https://www4.bcb.gov.br/pec/taxas/port/ptaxnpesq.asp?frame=1

Bohan, A., Shalloo, L., Creighton, P., Earle, E., Boland, T. M., \& McHugh, N. (2018). Investigating the role of stocking rate and prolificacy potential on profitability of grass based sheep production systems. Livestock Science, 210, 118-124.

https://doi.org/10.1016/j.livsci.2018.02.009

Brasil. (2007). Decreto No. 882, de 29/05/2007, Diário Oficial No.7481. Retrieved March 20, 2016, from http://www.sefanet.pr.gov.br/SEFADocumento/Arquivos /2200700882.pdf.

Chwif, L., \& Medina, A. C. (2014). Modelagem e Simulação de Eventos Discretos: Teoria e Aplicações (4th ed.). Elsevier.

CONAB, C. N. de A. (2010). Custos de Produção Agrícola: A metodologia da Conab. Brasília, DF.

Croitoru, E. L., Toader, S. A., Silvia, O., \& Pletescu, C. (2015). The impact of fiscal depreciation over the economic and fiscal performance of the company. Romanian Economic and Business Review, 10(2), 119-130. Romanian-American University. Retrieved June 7, 2019, from

https://go.galegroup.com/ps/i.do?id=GALE\%7CA490208953\&sid=googleScholar\&v=2.1\&it $=$ r\&linkaccess $=$ fulltext $\&$ issn $=18422497 \& \mathrm{p}=\mathrm{AONE} \& \mathrm{sw}=$ w\&userGroupName $=$ usp_br

De Freitas Filho, P. J. (2008). Introdução à modelagem e simulação de sistemas : com aplicações em Arena (2nd ed.). Santa Catarina: Visual Books.

Demirhan, S. A. (2019). Sheep farming business in Uşak city of Turkey: Economic structure, problems and solutions. Saudi Journal of Biological Sciences, 26(2), 352-356. Elsevier. Retrieved June 7, 2019. https://doi.org/10.1016/j.sjbs.2018.10.004

Eales, A., \& Small, J. (2008). Abortion in Ewes. In F. A. Eales, J. Small, \& C. Macaldowie (Eds.), Practical lambing and lamb care : a veterinary guide (p. 247). Blackwell Pub.

FAO. (2017). Food and agriculture data.

Gouveia, A. M. G. (2006). Aspectos sanitários do sistema produtivo de caprinos e ovinos. Simpósio de Caprinos e Ovinos da Escola de Veterinária da UFMG (p. 9). Belo Horizonte: Embrapa. Retrieved June 7, 2014, from

https://www.bdpa.cnptia.embrapa.br/consulta/busca?b=ad\&id=532448\&biblioteca=vazio\&bu sca=autoria:\%22GOUVEIA, A. M. G.\%22\&qFacets=autoria:\%22GOUVEIA, A. M.

G. $\% 22 \&$ sort $=\&$ paginacao $=$ t $\&$ paginaAtual $=1$

Harrell, C. R., \& Bateman, R. L. (2002). Simulação: otimizando os sistemas. (2nd ed.). São 
Paulo: IMAM.

Hillier, F. S., \& Lieberman, G. L. (2006). Introdução à pesquisa operacional (8th ed.). São Paulo: McGraw-Hill.

IBGE. (2016). Instituto Brasileiro de Geografia e Estatística - Produção da Pecuária Municipal. Retrieved June 6, 2017, from

https://www.ibge.gov.br/estatisticas-novoportal/economicas/agricultura-e-pecuaria/9107-prod ucao-da-pecuaria-municipal.html?\&t=resultados

INSTITUTO FNP. (2010). Anuário da pecuária brasileira - Anualpec. São Paulo.

Kabir, M. J., Gaydon, D. S., Cramb, R., \& Roth, C. H. (2018). Bio-economic evaluation of cropping systems for saline coastal Bangladesh: I. Biophysical simulation in historical and future environments. Agricultural Systems, 162, 107-122.

https://doi.org/10.1016/j.agsy.2018.01.027

Kowalski, L. H., Fernandes, S. R., Monteiro, A. L. G., Chen, R. F. F., \& Stivari, T. S. S. (2013). Custos da terminação de cordeiros em sistemas com amamentação controlada e desmame precoce em confinamento e pastagem. $16^{\circ}$ Simpósio Paranaense de Ovinocultura. Pato Branco: Synergismus scyentifica UTFPR. Retrieved November 7, 2015, from http://revistas.utfpr.edu.br/pb/index.php/SysScy/article/view/1733

Law, A. M., \& Kelton, W. D. (1991). Simulation modeling and analysis (2nd ed.). New York: McGraw-Hill.

Machline, C., Motta, I. S. ., Weil, K. E., \& Schoeps, W. (1975). Manual de administração da produção (3rd ed.). Rio de Janeiro: Fundação Getúlio Vargas.

Manevski, K., Børgesen, C. D., Li, X., Andersen, M. N., Zhang, X., Abrahamsen, P., Hu, C., et al. (2016). Optimising crop production and nitrate leaching in China: Measured and simulated effects of straw incorporation and nitrogen fertilisation. European Journal of Agronomy, 80, 32-44. https://doi.org/10.1016/j.eja.2016.06.009

Martin, G., Martin-Clouaire, R., Rellier, J. P., \& Duru, M. (2011). A simulation framework for the design of grassland-based beef-cattle farms. Environmental Modelling and Software, 26(4), 371-385. https://doi.org/10.1016/j.envsoft.2010.10.002

Montevechi, J. A. B., Leal, F., Pinho, A. F., Costa, R. F. S., Oliveira, M. L. M., \& Silva, A. L. F. (2010). Conceptual modeling in simulation projects by mean adapted idef: an application in a brazilian tech company. Proceedings of the 2010 Winter Simulation Conference (pp. 1624-1635). Baltimore: Winter Simulation Conference.

https://doi.org/10.1109/WSC.2010.5678908

Paim, T. do P., Cardoso, M. T. M., Borges, B. O., Gomes, E. F., Louvandini, H., \& McManus, C. (2011). Estudo econômico da produção de cordeiros cruzados confinados abatidos em diferentes pesos. Ciência Animal Brasileira, 12(1), 48-57. Universidade Federal de Goiás. https://doi.org/10.5216/cab.v12i1.5894 
Pegden, C. D., Shannon, R. E., \& Sadowski, R. P. (1995). Introduction to simulation using SIMAN. New York: McGraw-Hill.

Pereira, T. F., Montevechi, J. A. B., \& Miranda, R. de C. (2013). Gestão do conhecimento em projetos de simulação: uma abordagem da espiral do conhecimento. XXXIII Encontro Nacional de Engenharia de Produção (pp. 1-19). Salvador: Associação Brasileira de Engenharia de Produção. Retrieved January 16, 2018, from http://www.abepro.org.br/biblioteca/enegep2013_TN_STO_184_052_22417.pdf

Pidd, M. (1996). Modelagem empresarial : ferramentas para tomada de decisão. Bookman. Retrieved June 7, 2019, from

https://books.google.com.br/books/about/Modelagem_empresarial.html?id=DUyYAAAACA AJ\&redir_esc $=\mathrm{y}$

Raineri, C., Stivari, T. S. S., \& Gameiro, A. H. (2015a). Lamb Production Costs: Analyses of Composition and Elasticities Analysis of Lamb Production Costs. Asian-Australasian Journal of Animal Sciences, 28(8), 1209-1215. Asian-Australasian Association of Animal Production Societies (AAAP) and Korean Society of Animal Science and Technology (KSAST). https://doi.org/10.5713/ajas.14.0585

Raineri, C., Stivari, T. S. S., \& Gameiro, A. H. (2015b). Development of a cost calculation model and cost index for sheep production. Revista Brasileira de Zootecnia, 44(12), 443-455. https://doi.org/10.1590/S1806-92902015001200005

Reijers, T. S. S. S. (2016). Desenvolvimento de modelo computacional híbrido - baseado em agentes e em simulação de eventos discretos - para avaliação e planejamento da produção animal: uma aplicação na ovinocultura de corte. Universidade de São Paulo.

Salgado, J. A. (2011). Sistemas de produção de cordeiros e seu efeito na infecção por helmintos gastrintestinais. Universidade Federal do Paraná.

Sargent, R. G. (2010). Verification and validation of simulation models. Proceedings of the 2010 Winter Simulation Conference (pp. 166-183). Baltimore: IEEE. https://doi.org/10.1109/WSC.2010.5679166

SEAB-PR. (2016). Pesquisa Anual de Preços de Terras Agrícolas - Secretaria da Agricultura e Abastecimento. Retrieved June 13, 2018, from

http://www.agricultura.pr.gov.br/modules/conteudo/conteudo.php?conteudo=30\#Conceito

Simplício, A. A., \& Azevedo, H. C. (2014). Reproductive management: focus on reproduction rate. Acta Veterinaria Brasilica, 8(supl.2), 320-331.

https://doi.org/10.21708/avb.2014.8.0.3949

Sorio, A., \& Rasi, L. (2010). Ovinocultura e abate clandestino: um problema fiscal ou uma solução de mercado? Revista de Política Agrícola, 19(1), 71-83. Retrieved June 7, 2012, from https://seer.sede.embrapa.br/index.php/RPA/article/view/336

Souza, F. A. A., Lopes, M. A., \& Demeu, F. A. (2008). Panorama da Ovinocultura no Estado de São Paulo. Revista Ceres, 55(5). Retrieved February 7, 2015, from 
http://www.ceres.ufv.br/ojs/index.php/ceres/article/view/3529

Stivari, T. S. S. (2012). Análise econômico-financeira de produção de ovinos em pastagem. Universidade Federal do Paraná.

Stivari, T. S. S., Monteiro, A. L. G., Gameiro, A. H., Chen, R. F. F., Silva, C. J. A., De Paula, E. F. E., Kulik, C. H., et al. (2013). Viabilidade econômico-financeira de sistemas de produção de cordeiros não desmamados em pastagem com suplementação em cocho ou pasto privativo. Revista Brasileira de Saúde e Produção Animal, 14(3).

https://doi.org/10.1590/S1519-99402013000300001

Stott, A. W., Milne, C. E., Goddard, P. J., \& Waterhouse, A. (2005). Projected effect of alternative management strategies on profit and animal welfare in extensive sheep production systems in Great Britain. Livestock Production Science, 97(2-3), 161-171.

https://doi.org/10.1016/j.livprodsci.2005.04.002

Toro-Mujica, P., García, A., Gómez-Castro, A. G., Acero, R., Perea, J., Rodríguez-Estévez, V., Aguilar, C., et al. (2011). Technical efficiency and viability of organic dairy sheep farming systems in a traditional area for sheep production in Spain. Small Ruminant Research, 100(2-3), 89-95. https://doi.org/10.1016/j.smallrumres.2011.06.008

Van Wyk, J. A., \& Bath, G. F. (2002). The FAMACHA system for managing haemonchosis in sheep and goats by clinically identifying individual animals for treatment. Veterinary Research, 33(5), 509-529. https://doi.org/10.1051/vetres:2002036

Viana, J. G. A., \& Silveira, V. C. P. (2009). Análise econômica da ovinocultura: estudo de caso na Metade Sul do Rio Grande do Sul, Brasil. Ciência Rural, 39(4), 1176-1181. https://doi.org/10.1590/S0103-84782009005000030

Wang, C. T., \& Dickerson, G. E. (1991). Simulated effects of reproductive performance on life-cycle efficiency of lamb and wool production at three lambing intervals. Journal of Animal Science, 69(11), 4338-4347. https://doi.org/10.2527/1991.69114338x

Ziguer, E. A., Tonieto, S. R., Pfeifer, L. F. M., Bermudes, R. F., Schwegler, E., Corrêa, M. N., \& Dionelllo, N. J. L. (2011). Resultados econômicos da produção de cordeiros em confinamento utilizando na dieta casca de soja associada a quatro fontes de nitrogênio não-proteico. Revista Brasileira de Zootecnia, 40(9), 2058-2065.

https://doi.org/10.1590/S1516-35982011000900030

\section{Copyright Disclaimer}

Copyright for this article is retained by the author(s), with first publication rights granted to the journal.

This is an open-access article distributed under the terms and conditions of the Creative Commons Attribution license (http://creativecommons.org/licenses/by/4.0/). 